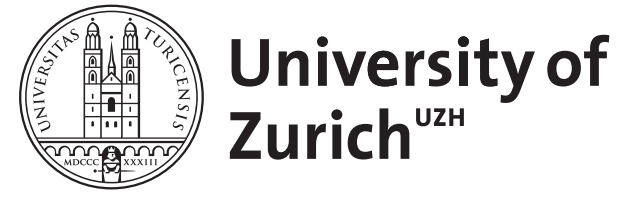

Zurich Open Repository and Archive

University of Zurich

University Library

Strickhofstrasse 39

CH-8057 Zurich

www.zora.uzh.ch

Year: 2013

\title{
Economic bases of communication
}

Siegert, Gabriele ; von Rimscha, M Bjørn

DOI: https://doi.org/10.1515/9783110240450.123

Posted at the Zurich Open Repository and Archive, University of Zurich

ZORA URL: https://doi.org/10.5167/uzh-73425

Book Section

Published Version

Originally published at:

Siegert, Gabriele; von Rimscha, M Bjørn (2013). Economic bases of communication. In: Cobley, Paul; Schulz, Peter. Theories and Models of Communication. Berlin: de Gruyter Mouton, 123-146.

DOI: https://doi.org/10.1515/9783110240450.123 


\title{
Gabriele Siegert and Bjørn von Rimscha 7 Economic bases of communication
}

\begin{abstract}
This chapter provides a general introduction to the essential economic issues of communication, both interpersonal and mediated. It covers economic concepts and methods relevant to the field. The focus is on mass communication and media economics, however featured concepts such as network effects and issues of regulation are also relevant for interpersonal communication. Furthermore it discusses concentration, internationalization, and convergence as three fundamental developments in media systems that tend to blur clear cut distinctions between media technologies and areas of research.
\end{abstract}

Keywords: Media markets, good characteristics, media regulation, business models, value-chain, network effects, media concentration, convergence, internationalization

Economic considerations related to communication generally focus on mass communication and mass media. Media economics has a long research tradition, although different periods were dominated by different theoretical approaches. For example, in Europe, critical political theory approaches dominated the 1970s through the late 1980s. In the 1990s, though, media economics research started to use traditional economic and management theories, models, and concepts of neoclassical and institutional economics. Economic considerations are less common in the context of interpersonal or group communication. For a long time, research on telecommunications did not refer to communication science explicitly.

Taking the research history into account, the following article focuses on media economics but also briefly covers aspects of interpersonal communication. The article is divided into four sections and starts with a general introduction to the essential economic issues of communication, both interpersonal and mediated. Section 2 covers economic concepts and methods relevant to the field. The discussion will focus on mass communication and media economics, although concepts such as network effects and issues of regulation are also relevant for interpersonal communication. Section 3 discusses concentration, internationalization, and convergence as three fundamental developments in media systems that tend to blur clear cut distinctions between media technologies research. Section 4 provides an overview and outlook to conclude the article. 


\section{Fundamental economic challenges in communication}

Interpersonal communication is a precondition of any economic activity. Before any kind of transaction can take place, individuals must communicate even if they do so as the representative of a larger corporate body. Information must be available for markets to be functional (Baumol and Blinder 2006: 195), and more often than not, it is gathered through interpersonal communication be it face-to-face or mediated through a carrier medium. Individuals negotiate prices or discuss how a task is to be carried out. The expectancy-value theory (Fishbein and Ajzen 1975) addresses the question of how much effort should be made to make a persuasive message credible. It suggests that the persuasiveness of a suggestion equals the promised value (or harm) multiplied by the perceived probability of its occurrence. The Harvard concept (Fisher and Ury 1981) also offers an economic perspective on interpersonal communication as it tries to make personal negotiations both successful and efficient. However, usually interpersonal communication itself is not the traded matter; only personal counselors or psychologists get paid for the act of interpersonal communication. Thus, when analyzing communication, economists usually concentrate on mediated communication, or mass communication.

In modern societies, successful mass communication relies on mass media systems that meet important socio-political and cultural expectations. Society expects the media to provide information, to entertain people, to create publicity for various issues, to criticize, and, to a certain extent, control activities and protagonists, in particular those concerning politics and the economy. Some researchers doubt a commercial media system relying on free markets and market-oriented media companies can meet these expectations. Instead of quality news coverage that supports the political debate, society might then have to face "news that's fit to sell" (Hamilton 2004) or "market-driven journalism" (McManus 1994). The debate on the commercialization of the media (Croteau and Hoynes 2001; Gandy 2004; Picard 2004, 2005a; Siegert 2001b, 2003; McQuail 1998; Bagdikian 2000; Napoli and Gillis 2006) addresses this issue and discusses the consequences of market considerations becoming ever more important in the daily work of media organizations. Following the arguments of the commercialization debate tends to result in media production that does not serve the public interest. However, it is also discussed whether media brand reputation as an institutional arrangement could help media markets to better work in respect of the public interest (Siegert et al. 2008; Siegert et al. 2011).

In addition, the importance of a functioning mass media system is only partly reflected in the economic size of the industry. The percentage that the media contributes to the gross domestic product (GDP) differs according to the market definition (see Section 2.2) from $0.21 \%$ for broadcast media in Germany in 2009 (ALM 
2010) to $6.0 \%$ for copyright-based industries in the United States in 2002 (Siwek 2004: 3). These numbers only represent the economic dimension of the media, and thus tremendously underestimate the significance of the industry for society. Luhmann (1996: 9) stated: "What we know about our society, indeed the world in which we live, we learn from the mass media". Therefore, any account of the media as economic good must also pay respect to the importance of the media as a cultural good that shapes our opinions, influences our values and norms, and provides us with conversation topics to build social capital. The dual character as economic and cultural good poses a challenge to regulation (see Section 2.4). ${ }^{1}$

Both interpersonal and mass communication markets show large externalities due to network effects (see Section 2.6). Thus, business models in communication are routinely based on two-sided markets and mixed funding (see Section 2.5).

\section{Economic concepts and models}

In this section, we will discuss economic concepts and models mainly focusing on mass communication. However, many of the presented concepts are relevant for interpersonal communication too, and this will be pointed out where appropriate.

\subsection{Media as economic good}

Most introductions to media economics mention the unique characteristics of media goods, which exert major influence on how media markets work and what kinds of strategies fit in media business (Doyle 2002: 11; Kiefer 2005: 130-160; Picard 1989: 17-19, 2005b; Heinrich 2010: 25-43). ${ }^{2}$

Taking 'packaged and delivered content' as a starting point, it is discussed throughout the literature whether media goods are public goods and/or merit goods and how to handle externalities. These characteristics are sources of the inefficiency of resource allocation and consequential of market failure (see Section 2.4). Public goods are non-excludable (exclusion of potential users is either

1 The difference between media as economic and as cultural good is also important in the production of media. A special characteristic about media products is the level of dedication and commitment that the content producers - be it journalists or film directors - show toward their work. Creative workers care about their product (Caves 2000: 3), and thus value not only the monetary compensation, but also a creative satisfaction.

2 Most authors refer to the packaged and delivered content as media good. Only a few contributions include access to audiences as marketed service, and almost none consider that the key characteristics change along the value chain. We like to address this problem simply by mentioning that on the business-to-business market, where content producers deal with media distributors, the traded good does not feature most of the listed unique characteristics. 
impractical or impossible), which leads to free rider problems, and are non-rivalrous (consumption by one person does not lessen the amount available for others), which makes exclusion inefficient. In particular, free-to-air broadcasting is said to be a public good.

Putatively, the consumption of media content can have positive external effects, such as citizens being well-informed and making enlightened choices, as well as negative external effects, such as citizens exhibiting violent behavior. Both effects are not included in the price of media content: society either benefits from it or has to pay for it. Society expects the media to provide content with positive external effects, but unfortunately this content often does not generate a great consumer demand. In a normal market relationship, profit-maximizing suppliers therefore would fail to meet society's demand for such a service. This does not mean that merit goods will not be offered in a market with profit-maximizing suppliers, but the socially desirable output level will be higher than the market efficient output level (Demsetz 1970). That makes part of the media content a merit good.

Furthermore, the media industry is characterized by high first copy costs, economies of scale, and economies of scope. High first copy costs imply that fixed costs of media production are high and independent of the amount of copies made, while variable costs are relatively low. This tends to result in decreasing the average fixed costs by increasing output (economies of scale). Due to the costs of physical production and distribution of copies, this effect is stronger in the audiovisual industry than in the print publishing industry and is most powerful concerning digital production and distribution. To sum up, large scale production is more efficient than small-scale production (Picard 1989: 62). Economies of scope "arise when there are some shared overheads for two or more related products to be produced and sold jointly, rather than separately. Savings may arise if specialist inputs gathered for one product can be re-used in another" (Doyle 2002: 13-14).

Additionally, media goods are characterized as experience and credence goods. Entertainment is regarded as an experience good, or a good with unknown characteristics whose quality and utility can only be judged after being used several times (Nelson 1970). Journalistic information, however, is regarded as a credence good. Credence good markets are characterized by asymmetric information between sellers and consumers (Darby and Karni 1973). Users are unable to fully measure the quality of media content. For example, they cannot judge whether information provided by a news broadcast meets journalistic quality standards because the background work, selection, investigation, and effective workload remain 'invisible,' or cannot be accessed for monitoring, and could only be evaluated by completely repeating the journalistic inquiry. Altogether, media users tend to rely on external information and market signals such as reputation and brand (Heinrich and Lobigs 2003; Lobigs 2004; Siegert 2001a, 2006a). Charging users for an experience good or a credence good is difficult. People might not be willing to pay before 
they can access the good, and if they have experienced it they most likely will not want to pay for something they already experienced. This renders indirect financing through advertising an expeditious alternative.

Last but not least, uncertainty in the media production process and copyright problems are also characteristics that lead to imitation rather than innovation as a preferred strategy of media companies. The characteristics of media content do have consequences regarding financing. In the media business, frequently revenue is not immediately connected to transactions. Readers often pay a subscription fee for their newspaper; advertisers pay for advertising space and assumed attention but cannot be sure that anybody will see it. The license fee for public service broadcasters has to be paid independently from the use of the public channels.

\subsection{Defining relevant media markets}

Defining the relevant market involves clarifying the market structure and is closely related to the state of competition. Usually four types of competitive market structure are differentiated: perfect competition, monopolistic competition, oligopoly, and monopoly. Following the Structure-Conduct-Performance (SCP) paradigm, analyzing the market structure includes at least the number of sellers and buyers, product differentiation, cost structures, vertical integration, and barriers to entry for new competitors. The market structure determines the state of competition, the context for strategies, and the resulting performance of companies (Scherer 1980; Chan-Olmsted 2006: 163).

It is essential to define the relevant market in order to assess its market power and the intensity of competition in a (media) market, as well as to align (media) strategies with the competitive environment. "Defining a market involves specifying the good/service markets involved and combining that description with a specific geographic market description" (Picard 1989: 17). The generally used 'relevant market concept' is based on the substitutability of goods or services; from the average consumer's perspective, (media) products and services can easily replace one another and compete in the same market.

Throughout the literature on media economics and media management, it is given that most media companies operate in a dual-product market by participating in an audience market as well as in an advertising market (see Section 2.3). However, the different media are not fully interchangeable with one another due to technological standards, product differences, and usage patterns. Therefore, it once was assumed that different media technologies (newspaper, magazines, television, and radio) do not compete with each other, whereas companies dealing with the same media do (intramedia competition). Among changing technological standards, though, consumer tastes and usage patterns have led to increasing intermedia competition and also challenged the precise definition of the relevant 
market. The topics covered and the corresponding target groups increasingly determine the boundaries of media markets rather than media technologies.

In addition, it is important to clarify the geographical dimension of media markets. Due to the interests of audiences, some media firms market their outlets locally or regionally, yet others sell them nationwide or, in some cases, internationally. Global media outlets are an exception, although the activities of transnational corporations force competition on an international level (Gershon 2006; SánchezTabernero 2006). The geographical dimension is only one factor that influences the size of a media market; it refers partly to the size of the audience that could be interested in a certain media outlet. However, media outlets are also closely connected to certain geographical areas for cultural and political reasons. They relate to a certain political system's events and actors, to languages, to different patterns of media usage, and to a common cultural identity. The market size, on the other hand, is important because of the effectiveness of key economic characteristics of media products (fixed cost degression, economies of scale, partly economies of scope). The bigger the market in which a media company operates, the more effective are these characteristics - operating in a big market is a competitive advantage. Small media markets are a key characteristic of so-called small countries and therefore foster regulation (see Section 2.4).

\subsection{Dual-product market}

Some media technologies such as books or recorded music rely almost entirely on direct sales to recipients. Producers offer one product in one market and the audience's interest should be their only benchmark. However, more often than not, media are financed simultaneously from several different sources. A newspaper publisher derives revenue from the copy price as well as from advertising sales. A public broadcaster might add some advertising revenue to its license fee, but a free-to-air TV channel might rely almost entirely on advertising revenue. In these cases, media firms operate in a dual-product market (Picard 1989), which means that media firms produce and market one product - content - in an effort to simultaneously produce and market a second product - audience attention. Economists speak of a two-sided market (Rochet and Tirole 2006) where the business model considers viewers as a loss leader, which in turn attracts advertisers. Success or failure in the market for audience contacts is a function of success or failure in the market of content for recipients, and vice versa. A broadcaster or publisher that fails to attract a reasonably large or demographically desirable audience has a relatively unappealing product to sell in the advertising market. The same broadcaster or publisher therefore will not have the financial resources (relative to its competitors) to produce content capable of attracting a larger or more desirable audience since prices for readers or viewers are subsidized (Kaiser and Wright 
2006). Thus, the audience and advertising markets are tightly intertwined, even if all revenue is derived from the advertising market.

This dual-product market would not work, though, without well-established and accepted commercial audience research (Ang 1991; Siegert 1993: 15; Ettema and Whitney 1994; Webster et al. 2006; Frey-Vor et al. 2008). Therefore, commercial audience research is discussed as an indispensible market information system (Phalen 1998). It measures, segments, and rates the audience of past programs and provides estimates of the future audience. As a result, it makes the invisible and sometimes unknown audience visible and marketable to advertisers. Ratings are one of the most common examples of commercial audience research and have found their way into popular culture.

\subsection{Market failure and regulation}

Broadcast media in particular are regarded as a prime example of a public good (see Section 2.1). The characteristics of public goods lead to market failure because, if no one can be excluded from the use of a commodity, people will try to get a free ride and the willingness to pay will converge to zero. If the consumption of a commodity by one person does not restrict availability for others, the commodity is not scarce, and thus, again, it is impossible to discriminate using the price mechanism. In most European countries, legislators introduced public service media to address market failure, which ensured that consumers pay for the media via the license fee or taxes while maximizing the public good to society's benefit (Graham 1999). Commercial broadcasters address the market failure by bringing in the advertising industry as a middle man. In this model, the broadcaster actually does not want to exclude anybody from consumption since the objective is to generate the most attention among recipients.

Technological progress rendered the issue of market failure partly obsolete once it became possible to exclude potential free riders using digital rights management or scrambled signals. Digitization also has increased the available supply and freed the medium from the limits of linearity. However, even in the digital media industry of the twenty-first century, public service media still exist because in addition to the public good character, an even more powerful argument for regulation lies in the merit good character of the media (Ward 2006). Media are said to feature positive externalities in wide areas of society with social benefits clearly exceeding private ones. Governments that identify a merit good with its positive impact on society usually introduce measures that maximize the consumption and supply of the desirable good or service, which is done by subsidies. In the case of broadcasting, the instrument of choice is the introduction of public service media; for newspapers and magazines, common measures include indirect measures, such as a reduced sales tax, and direct measures, such as reduced distri- 
bution fees (Fernández Alonso et al. 2006: 2). In the audiovisual sector, almost every developed country offers some form of subsidies in the shape of film funding schemes.

Public service media in small countries gain an outstanding importance. Small countries are characterized by small media markets and a shortage of resources. As a consequence, there are special constraints for small states: dependence and vulnerability (Trappel 1991; Meier and Trappel 1992; Siegert 2006b). Furthermore, small states struggle at times to protect their cultural heritage when confronted with the dominance of international content and content from larger neighboring states. Therefore, regulation in small states tends to interfere more directly with the content while allowing cross-media ownership for national champions (Puppis 2009). Also, public service media in small states are expected to support cultural national identity.

Providing platforms for interpersonal communication usually also involves dealing with regulation. Since network effects are deemed positive for society, regulators demand universal service for everybody and may set a low price for a basic service in order to include every citizen in the communication network. Communication networks often have the character of a natural monopoly which makes regulation even more necessary to prevent excessive tariffs (Meyer et al. 1980).

\subsection{Business and revenue models}

Business models connect media economics to media management by describing underlying characteristics of the industry sector that enable commerce in the product or service. Thus, media business models are not so much about daily business activities, but a fundamental concept of how the business can operate, what interfaces it offers for other industries, and what trade relations and financial interactions render it potentially successful. They can be described as structural design of the relevant flows of information, services, and, finally, products, and include an account of the necessary business activities and their reciprocal importance (Picard 2002). A business model consists of several submodels: procurement; market (demand, competition); goods and services; service offerings; distribution; and capital (funding, revenue). Additionally, a business model should include a description of the potential benefits of the various business actors and the sources of revenue. This constitutes the revenue model, which addresses questions regarding how revenue can be retrieved and from what sources, as well as what amount is necessary to finance the ongoing operations.

Revenue models can be distinguished by direct and indirect sources of revenue (Zerdick et al. 2000: 25) or by separating the relevant markets in which an organization is engaged (Wirtz 2009: 78). These two typologies can be applied both to mass communication and interpersonal communication platforms. 
In the first perspective, direct financing is most often obtained from the users, while indirect financing can be derived from companies (advertising) or the state (subsidies). The other perspective differentiates three markets where revenue can be realized: content markets, audience/user markets, and advertising markets. On content markets, media organizations trade licenses and exploitation rights, and the 'non-rivalrousness' of media use creates secondary markets. A broadcaster can sell the rights to a successful TV show to a different territory, or a publisher can license the concept of a successful magazine to another country. In addition, services and merchandise might be sold. It has nothing in common with interpersonal communication since usually it consists of inputs from two partners who will not bill each other for the words spoken during a conversation. From an economic perspective, issues of interpersonal communication mostly concern how to provide a platform where the communication takes place and then gain profit from operating that platform. Platforms for interpersonal communication do not need to be based on a technological network, but can be a coffee house where people meet for a hot drink and a chat. Overall, if we neglect the content market, interpersonal and mass communication have the same business models on the user and advertising markets. According to the concept of two-sided markets (Rochet and Tirole 2006), both markets are interdependent and connected via the price mechanism. Changes in price on the audience/user market influence the demand on the advertising market, and vice versa.

When looking at mass communication advertising markets, different advertising formats with associated recipient attention or recipient information can be sold. New means of interpersonal communication such as email services, chat rooms, and social networks on the Internet employ the same funding scheme as most mass media: selling attention to advertisers and selling consumer profiles to marketers. However, the quality of contact might be better than in mass media, and targeting of advertisements can be improved as social media networks struggle to capitalize on the attention of users. ${ }^{3}$ In the context of interpersonal communication, advertising might be considered even more intrusive when used as part of mass media content. We see the same tendencies toward ad avoidance on the consumer side, as well as the blending of content and advertising on the side of the platform providers and advertisers.

However, advertising does not constitute the only opportunity to bundle communication with another product or service to realize an indirect means of funding.

3 Recently, a new form of predominantly interpersonal communication (social online networks) has changed marketing since they enable corporations to establish quasi-interpersonal communications with potential consumers. In a social media network, the concept of a brand personality (Aaker 1997) is enlivened because it becomes possible to make friends with a brand and interact and communicate with it as if it were a real person (Burns 2010). In the course, brand communication becomes part of other interpersonal communications, for instance, when individuals pass on funny clips from a viral marketing campaign (Bauer et al. 2008). 
In the coffee house example mentioned earlier, the platform for interpersonal communication is funded by the price of a cup of coffee. Another example would be the price of Internet access that includes a personal email address. Because the platform is funded indirectly, though, providers have to make sure that the unpaid part of the bundle is not over used. Thus, Internet service providers introduce email quotas, and the coffee house's host might ask a lingering patron to either order another drink or leave, opening up the table for a new paying customer.

A network or platform operator who enables interpersonal communication can exclude potential users, and thus is able to charge whenever the network is used. This can be based on time or distance, e.g., when a telephone provider charges by the minute or a postal service sets different prices for letters to foreign countries depending on the distance required for delivery. As with newspapers, single payments can be replaced by subscriptions. Telephone providers in most countries now offer flat rates that allow users to use the network more or less without limits. Subscription models require that the average usage time results in costs below the net costs. Flat fees are a means to improve the capacity utilization if network costs are fixed. The same is true in the context of mass communication. Recipients can be charged for access to media or for media use. Again, there are subscription models that make the cash flow more predictable and also single payments for items in high demand that can seek a premium due to a willingness to pay. However, the merit good character of some media implies that the totaled individual willingness to pay cannot cover the production costs. Since the public has an interest in these media offerings, the state is an important fourth source of revenue or cost reduction. The media is considered important and influential for the political and cultural development and cohesion of a society, so in many countries the state supports the media by introducing a license fee to finance a public broadcaster (e.g., UK) or financing it directly through tax money (e.g., Spain). Most countries have reduced tax rates for media products and often the distribution is sponsored through subsidized postal fees. Film producers often enjoy tax breaks or even receive substantial direct financial contributions.

While interpersonal communication is predominantly financed directly through transmission charges, most media companies use mixed financing to spread risks while avoiding dependencies. The respective contribution of each revenue source depends on good characteristics as well as competition (Kind et al. 2009).

\subsection{Added value and value chain}

The concept of added value is derived from macroeconomic accounting where it is used to measure the contribution of an industry to the GDP. To analyze the performance of the media as an industry sector, market boundaries must be defined 
(see Section 2.2) and relations to other sectors up- and downstream need to be clarified. We can speak of a division of labor on an industry level, which in microeconomics can be described as value chain. The concept was introduced to business management by Porter (1985) as a succession of discrete activities for a firm operating in a specific industry. The products are taken through each of these activities and gain value every time they conclude a step. The chain of activities lends more added value to the product than the sum of added values of all activities.

The value chain can be used as a means to define markets - all firms on the same level compete with each other. It can also be used to conceptualize business models since it defines the interfaces between different steps in development from idea to reception. Typically the value chain for the media industry cannot use the element of the original concept with inbound logistics, operations, outbound logistics, marketing and sales, and service accompanied by overarching support activities such as infrastructure, human resources, technology, and procurement. With predominantly intangible input factors and output terms of classic inventory management become murky. Furthermore, the duality of the media as content and advertising vehicle complicates the structure (Wirtz 2009).

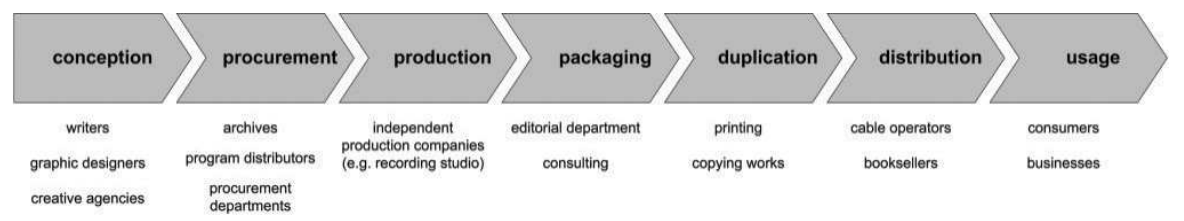

Fig. 1: Generic value chain in the media industry

There used to be distinct value chains for different media technologies with little, if any, overlapping between them. Changes in the technology and in the way the industry is organized have blurred the boundaries between technology-specific value chains and created a more generic multimedia value chain (see Fig. 1). Technological progress allows for disintermediation, or the systematic canceling of certain steps in the value chain. For example, electronic media such as radio and television do not have to be printed and copied, but can be directly distributed. Musicians who sell their recordings directly via the Internet skip procurement and integrate production, and if they use their own web site instead of platforms such as iTunes, they can even leap the packaging step. Convergence (see Section 3.2) has made this research perspective more complicated and less easily applicable.

\subsection{Network effects and network externalities}

Media content is often produced in networks by combining the expertise of different media workers. It is distributed using transmission networks and consumed by 
recipients who use media content as conversation subjects in their social networks. Thus, networks matter in media economics. Network goods differ from other goods concerning the value creation because of network externalities; consumers deciding between substitutable goods consider how their decision will affect others and how the decision of others will affect them. The utility that a user derives from the consumption of a network good increases with the number of others consuming the good (Katz and Shapiro 1985).

Generally, we can differentiate between direct and indirect network effects. In the first case, consumption externalities result from a direct physical effect of the number of purchasers on the product quality. A classic example would be a telephone network where the utility that a consumer derives from joining the network by buying access from the operator depends directly on the number of others who have already joined the network. Indirect network effects do not require a physical connection. When more consumers buy a certain kind of hardware, it increases the likelihood that a wide variety of different kinds of compatible software will be available for it. This phenomenon can be observed each time different standards for a new medium compete for user acceptance. For example, when consumers decide between HD-DVD or Blu-ray player disc technology, their individual decisions make one format more attractive than the other, since the home entertainment industry is likely to offer more movies in the more widely adopted format. The utility of a product increases with the greater availability of compatible complementary products.

For media content, an externality lies in the consumer capital for discussing common experiences when recipients have shared the experience of a certain content. But the case in point of network effects is the dual-product marketplace of traditional media (see Section 2.3). For users, network effects can lead to a lock-in due to high switching cost. For instance, a fan of a certain daily soap opera benefits from the fact that a large number of viewers watch the same show, and thus they have a common conversation topic. So this viewer might hesitate to switch to a competing soap airing at the same time because in addition to learning new characters and plotlines, s/he would not be able to talk about the new experience with those still watching the first show. Therefore, media companies can use network effects to tie the customers to their products.

However, network effects wear out as a network enlarges (Leibenstein 1950). The marginal benefit of one new user is much higher in a small network than in a big one. With the penetration of a phone network at almost $100 \%$, the value of that phone network does not further increase with a new installation.

Externalities result in economies of scale on the demand side. Larger companies with larger networks benefit more from externalities, thus their existence is a strong driver of concentration (see Section 3.1). This most often leads to natural monopolies in the case of broadcasting and telecommunication infrastructure (Posner 1969) since new entrants to the market cannot compete with the incumbent operator in terms of cost advantages and utility for users. 


\section{Fundamental developments in media systems}

\subsection{Media concentration}

Media goods feature several traits that make consolidation and concentration attractive. Since media content is unique, the costs of development are high. Consumers constantly demand novelty and their interests often are hard to predict, so production is risky. This means that being big is attractive in the industry. Economies of scale and scope lead to higher efficiency in larger companies. The advantage of size rests in the possible offset of risk and in the maximization of exploitation of content rights, especially in unit cost savings when first copy costs can be distributed over more copies. Furthermore, size brings about important advantages such as negotiation power with advertisers and improved access to capital. The latter proves important when new markets open up. Since the 1980s, only large companies have had the financial strength to enter the new broadcasting and telecommunication markets introduced when media policy ended a public service monopoly in much of the developed world (Picard 1998).

However, what is considered good from an entrepreneurial perspective might not be in the best interest of the society as a whole. Media concentration is regarded as a possible threat to diversity of ideas, tastes, and opinions. On the contrary, media diversity and media pluralism are considered prerequisites for effective freedom of expression and information (Meier and Trappel 1998). Even if we only consider economic aspects, though, concentration is not in the best interest of consumers. When the level of concentration reduces competition, it leads to higher prices, fewer choices, and poorer service for consumers. Concentration gives dominant firms control over resources that can be used against smaller firms in a competitive marketplace.

Concentration is not a new phenomenon. During the 1950s and 1960s, a consolidation of newspapers in several western European countries triggered extensive research (Aufermann and Heilmann 1970), but the deregulation of the audiovisual sector in Europe since the 1980s has pronounced the issue. Publishers expanded their operations to the TV sector, and thus claimed a bigger share of the media and opinion market as a whole. The professionalization of advertising and the emergence of huge international advertising networks serving brands that expand internationally have increased the pressure among media firms to grow and build market power.

We need to distinguish between different aspects of what is called media concentration:

- Horizontal concentration or mono-media concentration (Meier and Trappel 1998) looks at distinct media markets separated by geography or the means of distribution, e.g., the development of the market shares of British national newspapers. From an economic perspective, only horizontal concentration actually describes a concentration. 
- Vertical integration considers the effect of mergers and acquisitions on the concentration of power of one corporation across the value chain (see Section 2.6). If a TV network buys a big production company, this increases concentration neither in the broadcasting market nor in the production market. However, it increases the market power of that corporation and transforms a transparent exchange relationship on the market into internal affairs of that corporation.

- Cross-media or multimedia concentration (Sánchez-Tabernero 1993: 16) considers the media market as a whole where mergers and acquisitions among different media technologies (e.g., newspapers and broadcasters) not only create synergies but also increase market power in the overall 'market' of public opinion.

- Conglomerate concentration may occur when surplus capital from one industry seeks new business opportunities, or when new markets that open require considerable investment. The latter was the case when broadcasting was deregulated in France and Italy and commercial broadcasters were financed by banks or construction companies. For conglomerate concentration, different misgivings emerge. While the level of competition within the media market might not be reduced, chances are that the conglomerate tries to use its media ownership to influence the media content in its own best interest.

For cross-media concentration, the question arises: to what extent are the markets actually separated? Consumers as well as advertisers might use different media as substitutes so that they form a common relevant market. Thus, the concentration of ownership does not always imply less diversity in content. When two newspapers in the same region merge, it is likely that the content of the merged newspaper is less diverse. However, if a newspaper from another region, or if the dominant national TV chain buys a regional newspaper, neither the size of the staff nor the diversity of the content in that market have to change.

In markets for communication infrastructure, there is a tendency toward a natural monopoly. The high costs of setting up a cable infrastructure or of running a satellite distribution system prohibit the building of two competing networks. While there usually is competition between different distribution channels, each channel is run by a regional monopolist. In this context, it is evident that technological progress can at times reduce the potentially harmful effect of concentration. The development of digital subscriber line (DSL) technology enabled telephone operators to compete with cable operators, not only in the new field of data traffic, but also in the market for TV distribution. The Internet has vastly expanded the news sources available to recipients. Citizens living in a region with a monopolist newspaper can read newspapers from other regions online or access firsthand information from other sources within their region. Technology leads to fragmentation, so owning several media outlets does not necessarily lead to concentration, but can be regarded as a means to retain market share. Depending on the market in question, concentration is not always on the rise. 
Media concentration policy tries to control the potentially harmful effects of media concentration. Policy instruments differ widely between different countries; however, some measures seem to be prevalent. Either the number of media outlets or the market share that may be controlled by a single company is limited. Often cross-media ownership also is limited, meaning that a dominant player in one media technology may not expand into another to keep competition between the two genres alive.

However, studies about the effect of media concentration policy in general, and press concentration in particular, suggest that the measures are not effective. In some cases, there are even unintended outcomes ultimately favoring big integrated media corporations (Tunstall 1996; Knoche 1997).

\subsection{Convergence}

Changing technological standards challenge the body of acquired knowledge concerning media markets, value chains, and media business models. They provide the bases for variation and innovation on different levels - mostly analyzed by using the convergence concept. The concept of media convergence has multiple meanings and includes various changes in media's environments and behavior. Across the literature (e.g., overview by Wirth 2006; articles in IJMM 2003, No. 1 or the journal Convergence), convergence is seen as a multidimensional process that comprehends:

- Technological convergence (e.g., innovation, digitization, standardization)

- Economic convergence (e.g., merging of formerly divided markets, reconfiguration of value chains)

- Social convergence/convergence in media usage (e.g., consumer preferences and behavior)

- Cultural convergence (e.g., cross-media storytelling and mutual interrelated content)

- Policy convergence (e.g., deregulation, liberalization, convergence of formerly separate regulatory bodies and models)

- Global convergence (e.g., internationalization of strategies and content)

Additionally, the various dimensions should not be regarded as isolated, but rather as co-evolutionary developments (Latzer 1997). Some authors doubted whether consumer preferences and behavior would change (Stipp 1999; Höflich 1999). However, recent research results show that the use of online content increases and affects the use of traditional media and the definition of media markets (Gerhards and Klingler 2007; de Waal et al. 2005; Cole 2004; van Eimeren and Frees 2009).

From the perspective of media companies, convergence appears as reconfiguration of value chains and, following Wirth (2006), searching for synergy, increasing 
mergers and acquisition activities, and repurposing content on new media platforms. As discussed, value chains of the telecommunication industry, IT industry, and media industry merge into a convergent value chain. Telecom, IT, and media companies develop new business segments and pursue cross-media strategies. They increasingly operate in a common convergent market and have to face new competitors with different backgrounds, as shown in Fig. 2.

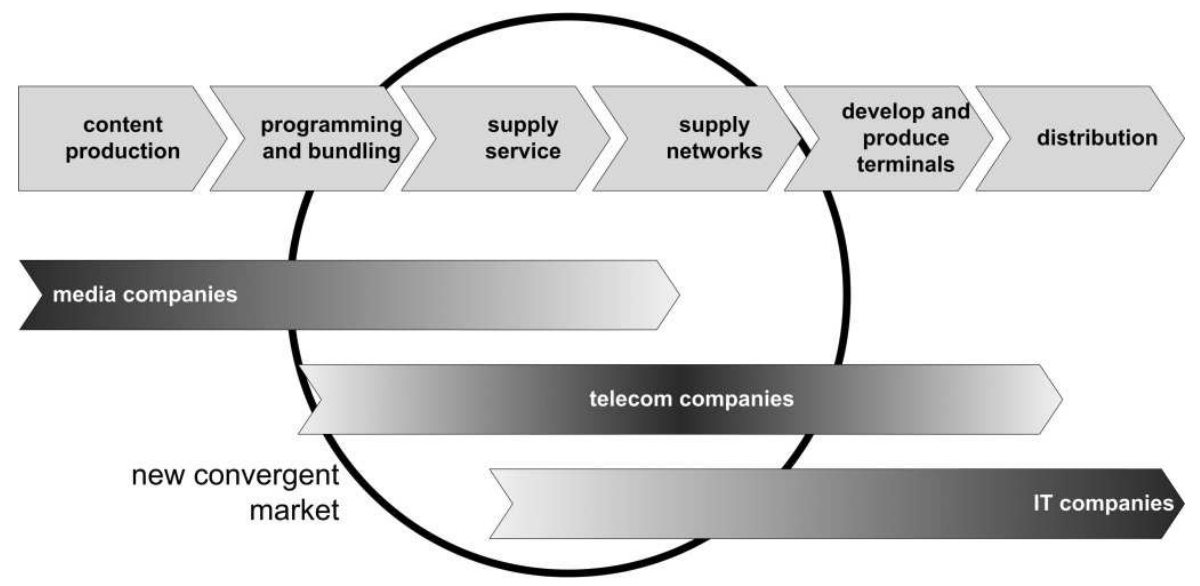

Fig. 2: Convergent value chains and markets

The rise of the Internet in particular has affected the business model of traditional media companies and gave a boost to free content. Although the demand for free content is high, the revenue model unfortunately does not pay off for media companies. Against the background of the last two economic crises (2000/2001: the burst of the so-called dotcom bubble, and 2008/2009: the worldwide financial crisis) media companies continuously complained about their role as producers of high-quality journalism without receiving adequate funding. While traditional media companies have to pay for the immense costs of good media coverage, Apple and Google realize profits with ad search and online advertising.

\subsection{Internationalization}

In recent decades, the media industry has evolved from clearly separated markets, in which family-owned businesses arranged themselves in a setting of low competition, to an international industry (Smith 1991; Demers 2002). Bertelsmann, for instance, was founded in 1835 as a publisher in North Rhine-Westphalia and now has about 500 newspaper and magazine titles in 30 countries, holds TV and radio stations in ten European countries, and produces TV content in 22 countries and licenses content in 150 countries. 
Internationalization is driven by two factors. First, media companies have an interest in expanding across borders; second, media recipients have a certain interest in foreign content (Sánchez-Tabernero 2006). Saturated national markets and barriers to cross-ownership force growing media companies to enter foreign markets. Generally, there are three strategies to enter a foreign market (Hafstrand 1995). The simplest way is to export ready-made media products. While this requires only small investments to achieve economies of scale, it is only feasible when the market entered is nearby and similar in culture and demand structure. This way of internationalization is common between neighboring countries sharing the same language, e.g., French media in Belgium, or German media in Austria and Switzerland. Another option is foreign direct investment, either in the form of joint ventures, mergers and acquisitions, or greenfield, i.e., starting a new operation from scratch (Gershon 2000). Foreign direct investment provides a high degree of control but requires a similarly high level of resources and commitment. The strong cultural component of the media industry renders a greenfield strategy less attractive since it does not allow building from knowledge of the new market. The third strategy is licensing where a firm in the host country is permitted to use a (intangible) property of the licensor such as trademarks, patents, production techniques, or content templates. Licensing requires very little investment, but it does not allow for generating revenue from production and marketing in the host country. Even more important, licensing includes a transfer of know-how that also might be utilized beyond the licensed product, and thus could strengthen possible competitors.

Apart from the upsides in terms of economies of scale and scope and new growth opportunities, internationalization also poses some problems for media companies. Media content is highly dependent on the cultural context. For instance, only a fraction of news content can be reused in other markets since most news broadcasts are relevant only in a certain market and recipients, as well as advertisers, are interested in local, regional or national content (Reid et al. 2005; Aldridge 2003). Entertainment content generally travels more easily, although cultural and linguistic borders exist as well. Supported by powerful global distribution and marketing, Hollywood movies are quite successful in foreign markets, and the very basic storylines of Latin American telenovelas make them universally deployable.

Nevertheless, there is a cultural discount for media content. Since media content distributed in a foreign market does not completely address the cultural framework, it will most likely draw a smaller audience, and thus be less valuable (McFadyen et al. 2000). Non-fiction programming is harder to transfer from one market to another due to its reliance on personalities (show host, celebrity guests, etc.). In this case, the strategy of choice is licensing, rather than exporting content. The emergence of an international trade in TV formats is a visible outcome of this relationship (Moran and Malbon 2006; Altmeppen et al. 2007). Instead of exporting complete shows, trade takes place via show templates that define game concept, 
the actor setting, and the dramaturgy. A format proven successful in one market offers reduced risk and required time to market in other markets while allowing for adjustments of the concept to local customs. This phenomenon is not limited to TV formats such as 'Who wants to be a Millionaire?' (Freedman 2001), but also happens with print magazines (Hafstrand 1995).

The other driving factor of internationalization is found in the recipients' interests. Cairncross (1997) diagnosed a "death of distance" where space is no longer the determining factor for social, information, and commercial relationships. Distance has become relative and this means the audience market becomes segmented by interests rather than by geographic factors. The "long tail" (Anderson 2006) for cultural goods can only work in a much expanded marketplace. Audience demand that was too obscure in the traditional media market becomes a viable market niche when search engines and recommendation systems allow recipients to find products outside of their geographic area. Of course, cultural and linguistic boundaries still remain, but with reduced cost for logistics, especially for digital products, exporting media content at a global scale is feasible even for specialized content.

\section{Outlook}

The fundamental importance of communication in modern societies is attended by the public interest in the economic bases of communication and the respective industry. Due to the various characteristics of interpersonal and mass communication, neither markets nor business models work as they do in other industries. The economics and management of media and communication are affected by the public and merit good character; the experience and credence good character of media content, externalities, and network effects; and economies of scale and scope. Furthermore, concentration, convergence, and internationalization tendencies not only challenge the media industry but the respective research and literature. It is an ongoing discussion whether the combination of characteristics makes it impossible for a commercial media system to serve the public interest, or whether there is a way to link quality and profit.

\section{Further reading}

Bagdikian, Ben H. 2000. The Media Monopoly, $6^{\text {th }}$ edn. Boston, MA: Beacon Press. Doyle, Gillian. 2002. Understanding Media Economics. London: Sage Publications.

Picard, Robert G. 2002. The Economics and Financing of Media Companies. New York: Fordham University Press.

Sánchez-Tabernero, Alfonso. 1993. Media Concentration in Europe: Commercial Enterprise and the Public Interest. Düsseldorf: European Institute for the Media. 
Wirth, Michael O. 2006. Issues in media convergence. In: Alan B. Albarran, Sylvia M. ChanOlmsted and Michael O. Wirth (eds.), Handbook of Media Management and Economics, 445462. Mahwah, NJ: Lawrence Erlbaum Associates.

\section{References}

Aaker, Jennifer L. 1997. Dimensions of brand personality. Journal of Marketing Research 34 (3). 347-356.

Aldridge, Meryl. 2003. The ties that divide: Regional press campaigns, community and populism. Media, Culture and Society 25 (4). 491-509.

Altmeppen, Klaus-Dieter, Katja Lantzsch \& Andreas Will. 2007. Flowing networks in the entertainment business: Organizing international TV format trade. The International Journal on Media Management 9 (3). 94-104.

Anderson, Chris. 2006. The Long Tail: How Endless Choice Is Creating Unlimited Demand. The New Economics of Culture and Commerce. London: Random House.

Ang, len. 1991. Desperately Seeking the Audience. London and New York: Routledge.

ALM (Arbeitsgemeinschaft der Landesmedienanstalten in der Bundesrepublik Deutschland) (ed.). 2010. Wirtschaftliche Lage des Rundfunks in Deutschland 2008 / 2009. Berlin: Vistas.

Aufermann, Jörg \& Peter Heilmann (eds.). 1970. Pressekonzentration: Eine kritische Materialsichtung und -systematisierung. München: Verlag Dokumentation.

Bagdikian, Ben H. 2000. The Media Monopoly. $6^{\text {th }}$ edn. Boston, MA: Beacon Press.

Bauer, Hans H., Thomas E. Haber, Carmen-Maria Albrecht \& Tom Laband. 2008. Viral Advertising. In: Hans H. Bauer, Dirk Große-Leege and Jürgen Rösger (eds.), Interactive Marketing im Web 2.0+: Konzepte und Anwendungen für ein erfolgreiches Marketingmanagement im Internet, $2^{\text {nd }}$ edn, 268-282. München: Vahlen.

Baumol, William J. \& Alan S. Blinder. 2006. Microeconomics: Principles and Policy. Mason, $\mathrm{OH}$ Thomson/South-Western.

Burns, Kelli. 2010. Brands among friends: An examination of brand friending and engagement on facebook. Paper presented at the annual meeting of the Association for Education in Journalism and Mass Communication, Denver, CO, Aug 04, 2010.

Cairncross, Frances. 1997. The Death of Distance: How the Communications Revolution Will Change Our Lives. Boston, MA: Harvard Business School.

Caves, Richard E. 2000. Creative Industries: Contracts Between Art and Commerce. Cambridge, MA: Harvard University Press.

Chan-Olmsted, Sylvia M. 2006. Issues in strategic management. In: Alan B. Albarran, Sylvia M. Chan-Olmsted and Michael 0. Wirth (eds.), Handbook of Media Management and Economics, 161-180. Mahwah, NJ: Lawrence Erlbaum Associates.

Cole, Jeffrey I. 2004. The Digital Future Report. Surveying the Digital Future: Ten Years, Ten Trends. Los Angeles: Digital Center.

Croteau, David \& William Hoynes. 2001. The Business of Media: Corporate Media and the Public Interest. Thousand Oaks: Pine Forge Press.

Darby, Michael R. \& Edi Karni. 1973. Free competition and the optimal amount of fraud. Journal of Law and Economics 16 (1). 67-88.

de Waal, Ester, Klaus Schönbach \& Edmund Lauf. 2005. Online newspapers: A substitute or complement for print newspapers and other information channels? Communications 30 (1). 55-72.

Demers, David P. 2002. Global Media: Menace or Messiah? $2^{\text {nd }}$ edn. Creskill, NJ: Hampton Press. 
Demsetz, Harold. 1970. The private production of public goods. The Journal of Law and Economics 13 (2). 293-306.

Doyle, Gillian. 2002. Understanding Media Economics. London: Sage Publications.

Ettema, James S. \& D. Charles Whitney. 1994. The money arrow: An introduction to audiencemaking. In: James S. Ettema and D. C. Whitney (eds.), Audiencemaking: How the Media Create the Audience, 1-18. Thousand Oaks: Sage Publications.

Fernández Alonso, Isabel, Miquel de Moragas, Jose J. Blasco Gil \& Nuria Almiron (eds.). 2006. Press Subsidies in Europe. Barcelona: Generalitat de Catalunya.

Fishbein, Martin \& Icek Ajzen. 1975. Belief, Attitude, Intention and Behavior: An introduction to theory and research. Reading, MA: Addison-Wesley.

Fisher, Roger \& William Ury. 1981. Getting to Yes: Negotiating Agreement Without Giving in. Boston: Houghton Mifflin Company.

Freedman, Des. 2001. Who wants to be a millionaire?: The politics of television exports. Information, Communication and Society 6 (1). 24-41.

Frey-Vor, Gerlinde, Gabriele Siegert \& Hans-Jörg Stiehler (eds.). 2008. Mediaforschung. Konstanz: UVK.

Gandy, Oscar H. 2004. Audiences on demand. In: Andrew Calabrese and Colin Sparks (eds.), Toward a Political Economy of Culture: Capitalism and Communication in the Twenty-First Century, 327-341. Lanham, MD: Rowman and Littlefield.

Gerhards, Maria \& Walter Klingler. 2007. Mediennutzung in der Zukunft: Eine Trendanalyse auf der Basis heutiger Datenquellen. Media Perspektiven 6. 295-309.

Gershon, Richard A. 2000. The transnational media corporation: Environmental scanning and strategy formulation. Journal of Media Economics 13 (2). 81-101.

Gershon, Richard A. 2006. Issues in traditional media management. In: Alan B. Albarran, Sylvia M. Chan-Olmsted and Michael O. Wirth (eds.), Handbook of Media Management and Economics, 203-228. Mahwah, N): Lawrence Erlbaum Associates.

Graham, Andrew (ed.). 1999. Public Purposes in Broadcasting: Funding the BBC. Luton: University of Luton Press.

Hafstrand, Helene. 1995. Consumer magazines in transition: A study of approaches to internationalization. Journal of Media Economics 8 (1). 1-12.

Hamilton, James T. 2004. All the News that's Fit to Sell: How the Market Transforms Information into News. Princeton, NJ: Princeton University Press.

Heinrich, Jürgen. 2010. Medienökonomie: Band 1: Mediensystem, Zeitung, Zeitschrift, Anzeigenblatt. $3^{\text {rd }}$ edn. Wiesbaden: VS Verlag.

Heinrich, Jürgen \& Frank Lobigs. 2003. Wirtschaftswissenschaftliche Perspektiven IV: Neue Institutionenökonomik. In: Klaus-Dieter Altmeppen and Matthias Karmasin (eds.), Medien und Ökonomie: Band 1/1: Grundlagen der Medienökonomie: Kommunikations- und Medienwissenschaft, Wirtschaftswissenschaft, 245-268. Wiesbaden: Westdeutscher Verlag.

Höflich, Joachim R. 1999. Der Mythos vom umfassenden Medium: Anmerkungen zur Konvergenz aus einer Nutzerperspektive. In: Michael Latzer, Ursula Maier-Rabler, Gabriele Siegert and Thomas Steinmaurer (eds.), Die Zukunft der Kommunikation: Phänomene und Trends in der Informationsgesellschaft, 43-59. Innsbruck: Studienverlag.

Kaiser, Ulrich \& Julian Wright. 2006. Price structure in two-sided markets: Evidence from the magazine industry. International Journal of Industrial Organization 24 (1). 1-28.

Katz, Michael L. \& Carl Shapiro. 1985. Network externalities, competition, and compatibility. The American Economic Review 75 (3). 424-440.

Kiefer, Marie L. 2005. Medienökonomik: Einführung in eine Ökonomische Theorie der Medien, $2^{\text {nd }}$ edn. München, Wien: Oldenbourg.

Kind, Hans J., Tore Nilssen \& Lars Sorgard. 2009. Business models for media firms: Does competition matter for how they raise revenue? Marketing Science 28 (6). 1112-1128. 
Knoche, Manfred. 1997. Medienpolitik als Konzentrationsförderungspolitik: Auch Österreich tappt in die Privatisierungsfalle. Medien Journal 21 (2). 14-25.

Latzer, Michael. 1997. Mediamatik: Die Konvergenz von Telekommunikation, Computer und Rundfunk. Opladen: Westdeutscher Verlag.

Leibenstein, Harvey. 1950. Bandwagon, snob, and veblen effects in the theory of consumers' demand. The Quarterly Journal of Economics 64 (2). 183-207.

Lobigs, Frank. 2004. Funktionsfähiger journalistischer Wettbewerb: Institutionenökonomische Herleitung einer fundamentalen publizistischen Institution. In: Gabriele Siegert and Frank Lobigs (eds.), Zwischen Marktversagen und Medienvielfalt: Medienmärkte im Fokus Neuer medienökonomischer Anwendungen, 53-68. Baden-Baden: Nomos.

Luhmann, Niklas. 1996. Die Realität der Massenmedien. $2^{\text {nd }}$ edn. Opladen: Westdeutscher Verlag.

McFadyen, Stuart M., Colin Hoskins \& Adam Finn. 2000. Cultural industries from an economic/ business research perspective. Canadian Journal of Communication 25 (1). 127-144.

McManus, John H. 1994. Market-Driven Journalism: Let the Citizen Beware? Thousand Oaks: Sage Publications.

McQuail, Denis. 1998. Commercialization and beyond. In: Denis McQuail and Karen Siune (eds.), Media policy: Convergence, Concentration and Commerce, 107-127. London: Sage Publications.

Meier, Werner A. \& Josef Trappel. 1992. Small states in the shadow of giants. In: Karen Siune and Wolfgang Treutzschler (eds.), Dynamics of Media Politics: Broadcast and Electronic Media in Western Europe, 129-142. London: Sage Publications.

Meier, Werner A. \& Josef Trappel. 1998. Media concentration and the public interest. In: Denis McQuail and Karen Siune (eds.), Media Policy: Convergence, Concentration and Commerce, 38-59. London: Sage Publications.

Meyer, John R., Robert W. Wilson, M. A. Baughcum, Ellen Burton \& John R. Meyer. 1980. The Economics of Competition in the Telecommunications Industry. Cambridge, MA:

Oelgeschlager Gunn and Hain.

Moran, Albert \& Justin Malbon. 2006. Understanding the Global TV Format. Bristol: Intellect.

Napoli, Philip \& Nancy Gillis. 2006. Reassessing the potential contribution of communications research to communications policy: The case of media ownership. Journal of Broadcasting and Electronic Media 50 (4). 671-691.

Nelson, Phillip. 1970. Information and consumer behavior. The Journal of Political Economy 78 (2). 311-329.

Phalen, Patricia F. 1998. The market information system and personalized exchange: Business practices in the market for television audiences. Journal of Media Economics 11 (4). 17-34.

Picard, Robert G. 1989. Media Economics: Concepts and Issues. Newbury Park, CA: Sage Publications.

Picard, Robert G. 1998. Media concentration, economics and regulation. In: Doris A. Graber, Denis McQuail, Pippa Norris and Doris Graber (eds.), The Politics of News: The News of Politics, 193-217. Washington DC: CQ Press.

Picard, Robert G. 2002. The Economics and Financing of Media Companies. New York: Fordham University Press.

Picard, Robert G. 2004. Commercialism and newspaper quality. Newspaper Research Journal 25 (1). 54-65.

Picard, Robert G. 2005a. Money, media, and the public interest. In: Geneva Overholser (ed.), The Press, 337-350. New York: Oxford University Press.

Picard, Robert G. 2005b. Unique characteristics and business dynamics of media products. Journal of Media Business Studies 2 (2). 61-69.

Porter, Michael E. 1985. Competitive Advantage: Creating and Sustaining Superior Performance. New York: Free Press. 
Posner, Richard A. 1969. Natural monopoly and its regulation. Stanford Law Review 21 (3). 548-643.

Puppis, Manuel. 2009. Introduction: Media regulation in small states. The International Communication Gazette 71 (7). 7-17.

Reid, Leonard N., Karen Whitehill King, Hugh J. Martin \& Hyeonjin Soh. 2005. Local advertising decision makers' perceptions of media effectiveness and substitutability. Journal of Media Economics 18 (1). 35-53.

Rochet, Jean-Charles \& Jean Tirole. 2006. Two-sided markets: A progress report. RAND Journal of Economics 37 (3). 645-667.

Sánchez-Tabernero, Alfonso. 1993. Media Concentration in Europe: Commercial Enterprise and the Public Interest. Düsseldorf: European Institute for the Media.

Sánchez-Tabernero, Alfonso. 2006. Issues in media globalization. In: Alan B. Albarran, Sylvia M. Chan-Olmsted and Michael O. Wirth (eds.), Handbook of Media Management and Economics, 463-492. Mahwah, NJ: Lawrence Erlbaum Associates.

Scherer, Frederic M. 1980. Industrial Market Structure and Economic Performance, $2^{\text {nd }}$ edn. Chicago: Rand McNally.

Siegert, Gabriele. 1993. Marktmacht Medienforschung: Die Bedeutung der empirischen Medienund Publikumsforschung im Medienwettbewerbssystem. München: Reinhard Fischer.

Siegert, Gabriele. 2001a. Medien Marken Management: Relevanz, Spezifika und Implikationen einer medienökonomischen Profilierungsstrategie. München: Reinhard Fischer.

Siegert, Gabriele. 2001b. Ökonomisierung der Medien aus systemtheoretischer Perspektive. Medien und Kommunikationswissenschaft 49 (2). 167-176.

Siegert, Gabriele. 2003. Im Zentrum des Taifuns: Die Ökonomisierung als treibende Kraft des medialen Wandels? Medien Journal 27 (1). 20-30.

Siegert, Gabriele. 2006a. Brands and reputation in principal-agent-relationships in the media industry. Paper presented at the $7^{\text {th }}$ World Media Economics Conference, Beijing, China, May 15-19, 2006.

Siegert, Gabriele. 2006b. The role of small countries in media competition in Europe. In: Jürgen Heinrich and Gerd G. Kopper (eds.), Media Economics in Europe, 191-210. Berlin: Vistas.

Siegert, Gabriele, Matthias Gerth \& Patrick Rademacher. 2011. Brand identity-driven decision making by journalists and media managers: The MBAC model as a theoretical framework. The International Journal on Media Management 13 (1). 53-70.

Siegert, Gabriele, Patrick Rademacher \& Frank Lobigs. 2008. Pessimistische Theorie Optimistische Praxis?: Unterschiedliche Sichtweisen auf die Konsequenzen der Ökonomisierung der Medien für deren seismographische Funktion in der Demokratie. In: Heinz Bonfadelli, Kurt Imhof, Roger Blum and Otfried Jarren (eds.), Seismographische Funktion von Öffentlichkeit im Wandel, 210-229. Wiesbaden: VS Verlag.

Siwek, Stephen E. 2004. The Economic Contribution of Copyright-Based Industries in USA: The 2004 Report. Washington DC: World Intellectual Property Organization.

Smith, Anthony. 1991. The Age of Behemoths: The Globalization of Mass Media Firms. New York: The Century Foundation.

Stipp, Horst. 1999. Convergence now? The International Journal on Media Management 1 (1). $10-14$.

Trappel, Josef. 1991. Born losers or flexible adjustment?: The media policy dilemma of small states. European Journal of Communication 6 (3). 355-371.

Tunstall, Jeremy. 1996. Newspaper Power: The New National Press in Britain. Oxford: Clarendon Press.

van Eimeren, Birgit \& Beate Frees. 2009. Der Internetnutzer 2009 - multimedial und total vernetzt: Ergebnisse der ARD/ZDF-Onlinestudie 2009. Media Perspektiven 7. 334-348. 
Ward, David. 2006. Can the market provide?: Public service media, market failure and public goods. In: Christian S. Nissen (ed.), Making a Difference: Public Service Broadcasting in the European Media Landscape, 51-64. London: John Libbey.

Webster, James G., Patricia F. Phalen \& Lawrence W. Lichty. 2006. Ratings Analysis: The Theory and Practice of Audience Research, $3^{\text {rd }}$ edn. Mahwah, NJ: Erlbaum.

Wirth, Michael O. 2006. Issues in media convergence. In: Alan B. Albarran, Sylvia M ChanOlmsted and Michael O. Wirth (eds.), Handbook of Media Management and Economics, 445462. Mahwah, NJ: Lawrence Erlbaum Associates.

Wirtz, Bernd W. 2009. Medien- und Internetmanagement, $6^{\text {th }}$ edn. Wiesbaden: Gabler Verlag.

Zerdick, Axel, Arnold Picot, Klaus Schrape, Alexander Artopé, Klaus Goldhammer, Ulrich T. Lange, Eckart Vierkant, Esteban López-Escobar \& Roger Silverstone. 2000. E-conomics: Strategies for the Digital Marketplace. Berlin: Springer. 
